\title{
THE EMERGENCE OF UNIVERSALISM AND THE DECLINE OF SUPRANATIONALISM
}

\author{
Sigit Riyanto* \\ Department of Internasional Law, Faculty of Law, Universitas Gadjah Mada, Yogyakarta \\ Jalan Sosio Justicia No. 1 Bulaksumur, Sleman, D.I. Yogyakarta, 55281
}

\begin{abstract}
In the context of addressing challenges of globalization there are many issues deserve to be discussed and elaborated. This paper addressed the three fundamental issues which are inseparable and interconnected each other: Spreading Universalism; Reinterpretation of Sovereignty, and the Decline of Supranationalism. The role of international organizations in the contemporary international system remain significant, however, constituents in the member States would judge whether they could maintain their relevance to the constituents interests and keep mutual relatianship with the member States.
\end{abstract}

Keywords: globalization, sovereignty, supra-nationalisme, universalism, multilateralism.

\section{Intisari}

Ada beragam persoalan yang layak diperdebatkan dan dijelaskan dalam mencermati tantangan globalisasi. Tiga persoalan mendasar dan saling terkait menjadi fokus bahasan dalam tulisan ini yakni: Universalisme yang makin meluas; re-interpretasi kedaulatan dan melemahnya supranasionalisme. Dewasa ini peran institusi internasional masih memiliki peran yang signifikan, namun, Negara-negara akan mencermati apakah institusi-isntitusi internasional ini mampu menjaga relevansinya terhadap kepentingan konstituen dan hubungan yangsaling menguntungkan dengan negara anggotanya.

Kata Kunci: globalisasi, kedaulatan, supra nasional, universalisme, multilateralisme.

\section{Pokok Muatan}

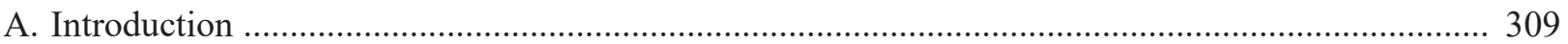

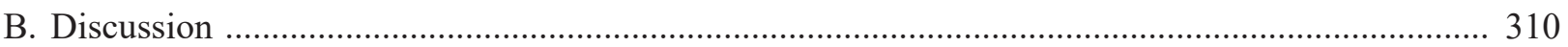

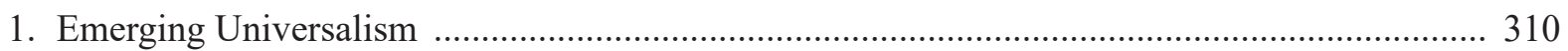

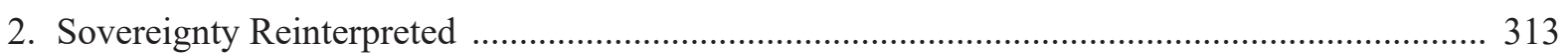

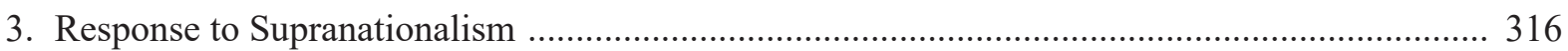

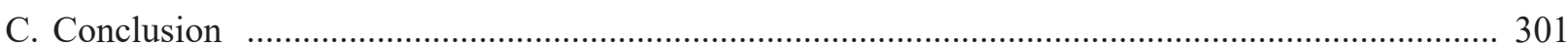

Email korespondensi: riyanto@gadjahmada.edu. 


\section{A. Introduction}

We are living in the era of transparancy, globalism and globalization. We have witnessed that our society has changed and is changing quickly. Tom Friedman is right when he was saying that the world is flat. ${ }^{1}$ The phenomenon of globalization compels States, individuals and corporations to compete not only at local or national level, but, at the international; and even in the global level.

As a scholar ever underlined that there is a possibility in which globalization force States in the "tri-lemma" situation. In this state of affairs, a State have to strike the balance concerning three interconnected issues: sovereignty, democratization, and liberalization. These issues are double-edged sword in the perspective that if we open ourselves to the liberalization process, then State sovereignty would be strained. In the meantime, if we give emphasize to democratization, then as consequence, we would be overriding the liberalization process and vice versa. $^{2}$

Anotherplausible argument why globalization is provoking debate, especially in the context of considering the role of international organization, recent trend have demonstrated that international organizations have become increasingly active players in the field of international law and policy making. This development interestingly, has not always and necessarily been calculated and anticipated by the Member States who have established the international organizations. ${ }^{3}$ In addition, there is a general feature in the international community in which certain International Organizations come to exist in all area of international relations; economic, social and political, and very unfortunately considerably limiting the outonomy of sovereign States. This development has serious consequences especially for third world States and peoples there in. In fact, the sovereign economic decision making authority has been relocated from the hand of States authority to certain international institutions such as : the World Trade Organization, the International Monetery Fund, the World Bank, and even to regional organisation such as the European Union. ${ }^{4}$ Consequently, the efficacy and legitimacy of international organizations and their decisions has become controversial, particularly in the last two decades, and frequently the issue has been critically dealt with from the perspective of the democracy deficit and accountability of such international organizations to the constituents in the member states. ${ }^{5}$

Thus, in the context of contemporary interStates relations, there are many issues deserve to be further discussed and elaborated when we are addressing challenges of globalization. In this paper, the present writer would like to address the three fundamental issues which are

In this regard, Friedman has pointed out that globalization could be interpreted as integration of markets, nation-states and technologies to a degree never witnessed before- in a way that enabling individuals, corporations and nation-states to reach around the world further, faster, deeper and cheaper than ever before, and in a way that is enabling the world to reach into individuals, corporations and nation-states farther, faster, deeper and cheaper than ever before.

It is interesting that in this context, Professor Dani Rodrik has ever outlined the three possible responses to this situation. First, ignore the problem and push for deeper globalization, at the cost of damaging cross-border consequences. Secondly, harmonize trade rules across the board, at the cost of imposing ill-fitting rules on all. Third, restrict globalization, at the cost of giving up some gains of trade. Furthermore, to address this conundrum, he proposed a compromise with the idea of "democracy-enhancing globalization". Unlike hyper-globalization, which justifies all rules that restrict democracy in the name of free trade, democracy-enhancing globalization would not undermine the legitimacy of the existing democratic institutions in the State concerned. In this framework, the democratic process would be exercised to open up markets and harmonize trade rules. He argues that globalization works best when it is not pushed too far, as this allows domestic authorities to retain adequate policymaking space. Hyper-globalization, where the free market runs unchecked, will eventually create a crisis of legitimacy as it will undermine many of the things citizens expect their state to provide; such as regulations regarding finance or product safety, a fair tax regime, redistribution, and institutional practices such as employer-employee bargaining. Ignoring the problems caused by globalization is, therefore, not an option for policymakers. See generally Dani Rodrik, "How to save Globalization from its Cheerleaders", The Journal of International Trade and Diplomacy, Vol.1, No. 2, 2007, pp. 1-33.

See Jan Wouters \& Philip De Man, 2009, International Organization as Law-Makers, Centre for Global Governance Studies Katholieke Universiteit Leuven, Leuven.

4 See for example B S Chimni, "International Institution Today: An Imperial Global State in the Making", European Journal of Internasional Law, Vol. 15, No. 1, 2004, p. 2.

Tetsuo Sato, "Legitimacy of International Organizations and Their Decisions- Challenges that International Organizations Face in the 21st Century", Hitotsubashi Journal of Law and Politics, Vol. 37, No. 2, 2009, pp. 11-30. 
inseparable and inter-connected each other. As a matter of fact, these issues have to be dealt with cautiously and vigorously. The three relevant and interconnected issues are: Spreading Universalism; Reinterpretation of Sovereignty, and the Decline of Supra-nationalism.

\section{B. Discussion}

\section{Emerging Universalism}

From my point of view as an international lawyer, there is tendency of a cross fertilization link between Human Rights and International Law, in the era of globalism and globalization across the globe. There are arguments that should be put forward to support this theory. The starting point for the debate on the linkage between human rights and international law should be derived from the legacy of the Grotius (1583-1645); especially concerning his doctrine on Humanitarian Intervention. ${ }^{6}$

Apart from that, we could also learn from the idea that legal norms are reflecting social standards, and the main interest in the effort of human rights protection has also been induced by changes of the individual attitude and governmental policy. The factual reasons regarding the strengthening of universalism in the contemporary international law and international relations can be ascertained as follow: "The strengthening of globalism and movement of encountering to "status quo".

Traditionally, scholars are divided into two mainstreams, namely, the "idealist" and/or "internationalist" paradigm vis-a-vis "realist " paradigm in the context of theorizing international relations. However, when States have to deal with the process of globalization and globalism; there is strong question on the "status quo" concept such as absolute State sovereignty. This question arises, especially when there are problems necessitate international and or trans-national approach. In fact, there is no State capable of handling the process of globalization and globalism alone. This is logical situation; particularly, in the case of responding transnational problems such as in the cases of international crime, terrorism, or even transnational organized crime. The national authority cannot use State's sovereignty as a shield in dealing with transboundary or transnational issues.

\section{a. The Urgency to Set The Rules On} Human Rights In The International Law

There might be a question on why human rights must be formulated and regulated under the international law and international relations. There are some points need to be taken into account in responding such a question. Firstly, it must be noted that in the aftermath of the World War II, individuals possess a legal standing before international court and constitute as one of the subjects of international law. Moreover, the international community through international organizations sets a standard for the protection of human rights, in the form of international legal instruments. This development is an indication of support and authorization of the international community in the legal codification of human rights. Furthermore, the international community also built the institutional structure of international protection for individual person.

\footnotetext{
Humanitarian intervention refers to armed interference in one State by another State(s) or International Organizations with the stated objective of ending or reducing suffering within the intervened State. That suffering may be the result of civil war, humanitarian crisis, gross violation of human rights, generalized of violence, or crimes by the first State including genocide. The goal of humanitarian intervention is neither annexation nor interference with territorial integrity, but minimization of the suffering of citizens, mostly civilians in that State. The claimed rationale behind such an intervention is the belief, embodied in international customary law in a duty under certain circumstances to disregard a State's unconditional sovereignty to preserve our common humanity and universal humanitarian values. Another definition suggested as follow : "Military action taken by a state or group of states, in the territory of another state against that state or its leaders, without that state's consent, which is justified partially or in whole by a humanitarian or protective concern for the population of the host state." See for example International Commission on Intervention and State Sovereignty (ICISS), 2001, The Responsibility to Protect: Report of the International Commission on Intervention and State Sovereignty, International Development Research Centre, Ottawa, p.1. See also Melissa Labonte, 2013, Human Rights and Humanitarian Norms, Strategic Framing, and Intervention Lessons for the responsibility to Protect, Routledge, New York, p. 24 .
} 
Hence, there are mechanisms and institutions have been developed and authorized in the context of human rights protection around the world. International community through international organization set up relevant institutions such as: The United Nations High Commissioner on Human Rights which later on has been transformed in to the Human Rights Council (HRC), The United Nations High Commissioner on Refugee (UNHCR), and needless to say, including the establishment of regional court in some regions, such as in Europe, Africa, and Inter-American. Although there is no specific regional Court for human rights in Asia, a dynamic discourse leading towards that idea is developing recently. Therefore, it must be underlined that the spreading and implementation of universal human right norms and values had been systematically advanced by States, International Organizations, individuals, and even Non-state Actors.

\section{b. The Human Rights Protection Internationally Institutionalized}

The internationalization of values and universal principles of human rights should be appreciated by observing the acceptance and implementation of human rights at the global level. As a scholar pointed out that any global moral vision must begin with human rights. The acceptance and development of a universal value and vocabulary affirming our commitment to human dignity and freedom both nationally and globally. This evolvement even has even been considered as the greatest ethical and political legacy of the twentieth century. ${ }^{7}$ The universal principles of human rights are appreciated and implemented by international, trans-national and national institutions. Implementation of universal human rights should not be relied on the consent of any state, however, it should be based on the universal validity of human rights. It then could be envisaged that this trend would likely uprising new challenges and developing legal norms that shall be taken into consideration and observed accordingly by States.

Institutionalization and enforcement of human rights norms by international community shall be seen as a commitment and concern of the international community for the adherence of values and effort of human rights protection around the world. Later on, we have witnessed that there is a new paradigm in the international community, in which human rights are derogating State sovereignty. This new paradigm has created an impetus for the development of international legal norms concerning State sovereignty restriction vis a vis human rights protection. Apart from standard setting adopted and established in the international legal instruments, additionally, such developments have also been reinforced by the establishment of International Criminal Court both in the form of an $\mathrm{Ad} \mathrm{Hoc}$ basis such as International Criminal Tribunal for the former Yugoslavia (ICTY) \& International Criminal Tribunal for Rwanda (ICTR as well as the permanent international court system: International Criminal Court upon the adoption of the Rome Statute in 1998. ${ }^{8}$ Thus, at this juncture, respect for and protection of human rights are crucial and should be considered as valid moral and legal judgement for the international humanitarian

Surakiart Sathirathai, "Renewing Our Global Values: A Multilateralism for Peace, Prosperity, and Freedom", Harvard Human Rights Journal, Vol. 19, 2006, pp. 1-28.

The Rome Statute of the International Criminal Court (often referred to as the International Criminal Court Statute or the Rome Statute) is the treaty that established the International Criminal Court (ICC). It was adopted at a diplomatic conference in Rome on 17 July 1998 and it entered into force on 1 July 2002. 
intervention in the contemporary international legal system. Human rights must be prioritize over sovereignty (Human Rights beyond sovereignty).

In this regards, it is interesting that in the development of contemporary international law and relations, there has been a process of functional evolution of human rights. In the first decade post-World War II, international community developed a process of "mind and standard setting". Specifically, there was an effort of the establishment of normative standards and also a mind-set nurturing that was commencing and directing to adopt universalism of human rights. In addition, humanity and human right values had been recognized and accepted by a States as a universal phenomenon that must be fought for and then have to be fostered accordingly. In the period of 1945-1960, human rights norms and values had a function as a legal and moral justification. In this respects there was a contention on the "status quo" based on universal human rights norms. Human rights norms and values have been referred as the foundation for the struggle against foreign rule and domination. In addition, in 19801990, many people in this world also recited human rights as referral in the movement to fight against dictatorial or domestic dictators.

Recently, in the 21th century, there is a multi-level government consolidation as an effort to uphold human rights as international law norm. Consequently, there is a "Multi-level Governance" framed as enforcement of international law. Since 1990s, there has been a justification in the international system to impose sanctions and to undertake humanitarian intervention and even the emergence of the doctrine of R2P (Responsibility to Protect). In this context, human rights considered to be more prominent than sovereignty, or in other words human rights beyond sovereignty.
This has been proven for example when the international community supported and implemented the establishment of international court in the form of an ad hoc basis such as International Criminal Tribunal for Former Yugoslavia (ICTY), International Criminal Tribunal for Rwanda (ICTR) and recently the establishment of a permanent tribunal; the International Criminal Court (ICC) based on the 1998 Rome Statute.

The reason behind the internationalization of human right values is that the perpetrators of human rights violations committed their action with the pretext of under their official capacity. In both de jure and de facto, the perpetrators are often a part of the State organs. In this sense, on behalf of their official title they can pretext to unleash their responsibilities and acquire the impunity. The human rights violations represent as violations against international rule. Thus, the responsibility is conferred to the individual as perpetrator of the committed crime. In this regard, the international community viewed that there is a universal interest to prevent repetition of similar crimes. The most important aspect is that there are disparities within and between countries in addressing human rights violations. In this context, there are issues regarding the failure from authority of the State in addressing human rights violations. The failure of States, due to their unable and or unwillingness to prosecute the wrongdoers will invoke the application of international protection as a complementary system.

\section{c. Protection of Human Rights as an Obligation Erga Omnes}

Eventually, there is strong argument to acknowledge human rights in the international law and international relation due to the following reasons. In the context of promotion, respect for and protection of human rights, it is generally agreed by 
international community that every State has the interest and obligation to ensure and accomplish according to the existing international legal instruments. For State, protection of universal human rights is an obligation erga omnes, consequently, should there is an action categorized as gross violation of human rights, there is obligation of every state to respond accordingly in line with the existing agreed international mechanisms for the sake of protecting the victims, preventing further casualties, restoration, and improvement of public order. ${ }^{9}$ This postulate has been supported and strengthened by legal doctrine $^{10}$ as well as judicial decisions (case law $)^{11}$ in the contemporary international legal system.

\section{Sovereignty Reinterpreted}

There are various definitions and concepts of State sovereignty in the study of international law and international relations. ${ }^{12}$ Sovereignty is a one of the fundamental concepts in the international legal system. In the context of international relations sovereignty refers to the independence and vice versa. An independent State is a State that possesses sovereignty, and a sovereign state is an independent State that is not under the control of other State.

In international law, sovereignty and equality are concepts that had been recognized as the foundation for the implementation of such a system. According to international law tradition, a state as an independent and sovereign entity means that it is not subject to the higher authority. ${ }^{13}$ Sovereignty and equality are attributes that are essential for an independent State as a subject of international law. The recognition State's sovereignty is the fundamental requirements to obtain legal personality in the international law system ${ }^{14}$. The State's sovereignty is also a foundation to exercise rights recognized by the international law, such as equality, territorial jurisdictions, right to determine nationality for the citizen in their territory, right to authorized and refused people to enter and leave State territory, or even right to nationalization ${ }^{15}$.

In the era of globalism, we are challenged with the expectation of finding out the new meaning of sovereignty. The new meaning of the sovereignty for the current context of our life must be assessed with the observation of the dynamic process in the international community. There are two factors that must be considered as catalist to determine the current situation, namely: (a) the development, spreading and implementation of universal values by international organizations, individuals and nonstates actors; and (b) the process of globalization, globalism, economic liberalization and international trade are increasingly and intensively widespread in the various regions of the world. Recently, as a consequence of globalization we have witnessed the integration of markets, nation-states and technologies to a degree never witnessed before in a way that enabling individuals, corporations and nation-states to reach around the world further, faster, deeper and cheaper than ever before; and in a way that is enabling the world to reach into individuals, corporations and nation-states farther, faster, deeper and cheaper than ever before.

In the present era of globalization, the traditional interpretation of State's sovereignty would likely also be considered as an obstacle in

9 W. Michael Reisman, “Legal responses to Genocide and Other Massive Violations of Human Rights”, Law and Contemporary Problem, Vol. 59, No. 4, 1996, pp. 75-76.

10 M. Cherif Bassiouni, "International Crime : Jus Cogens and Obligatio Erga Omnes “, Law and Contemporary Problem, Vol. 59, No. 4, 1996, pp. 63-74. See also Eric A Posner, 2008, Erga Omnes: Norms, Institutionalization, and Constitutionalism in International Law, Working Papers, University of Chicago Law School, Chicago . See also John M. Olin, 2008, Public Law and Legal Theory, Working Papers No. 224, University of Chicago Law School, Chicago.

11 See also the Barcelona Traction case [(Belgium vs Spain) (Second Phase) ICJ Rep 19703 at paragraph 33.

12 Jens Bartelson, "The Concept of Sovereignty Revisited," European Journal of International Law, April, 2006, p. 463.

13 See generally Miguel Gonzalez Marcos, 2003, The Search for Common Democratic Standards Through Internasional Law, Heinrich Boll Foundation, Washington, p. 1. See also Martin Dixon and Robert Mc. Corquodale, 2000, Cases and Materials on Internasional Law:Third Edition, Blackstone Press Limited London, p. 248.

14 Ian Brownlie, 1990, Principles of Public International Law Fourth Edition, Clarendon Press, Oxford, p. 287.

15 R.C. Hingorani, 1982, Modern International Law Second Edition, Oxford \& IBH Publishing Co., New Delhi, pp. $117-118$. 
encounter the humanitarian crises and the protection of fundamental citizen's right. Consequently, there are two different concepts of sovereignty: firstly, on the one hand sovereignty in the context of absolutism ${ }^{16}$ and secondly, sovereignty in the context of relativism.

The second concept of sovereignty, paralel with the development in the international society. Sovereignty in the contemporary international society has developed into the new meaning and context. Sovereignty is considered as relational tenet. Sovereignty is no more an as insular, close, narrow and restricted concept. However, it is an open and relational concept, emphasizing the capacity of establishing external relations rather than persistently rebuff external boost and support. Sovereignty should not be exploited as a pretext by the domestic authority to lock up from interaction wirth external parties. The capacity to engage external relationships and interact with external parties even would sthrengten the Sovereignty of the concerned State.

In this way, states as subject of international law should have a consensus and mutual dialogue among them and with the existing international institutions to find out a new meaning of sovereignty. The globalization process has also reflecting a reality that we are living in the era where the sovereignty cannot be exercised as a shield to limit the movement of peoples, assets, information, values and ideas. This situation also reflects the future global governance where globalization process and globalism, would eventually erode and eliminate the absolute sovereignty. As a result, some international law scholars believe that a new world order is emerging based on a complex web of transnational networks.
There are three patterns in which globalization and globalism seriuosly affected State sovereignty. Firstly, the expansion of trade and capital markets internationally have altered the State in controling its domestic economic matters. Secondly, as a response to globalization and globalism States have transfered and or delegated their powers towards international organizations. Thirdly, there are new norms of international law, more specifically norms relevant to international economic relations adopted and implemented by States and international institutions which are now recognized as the New Frontier of International Law" ${ }^{\prime 17}$. These new norms of international law which had been processed and institutionalized by international organizations especially the World Trade Organisation, in practice, limits the independence of the national authority on rule and policy making, which previously are fully retained in their hand ${ }^{18}$.

It is interesting to note that in such a context the former Director General of this organisation even underlined that WTO incorporates an integrated and distinctive legal order. Bringing together traditional international law, which it respects, and contemporary international law, which it is helping to promote. The WTO is both a product and a vehicle of that evolution. Indeed, the WTO is an international organization that brings together two concepts of international law. In fact, nowadays the WTO has become a part of the international legal order as a sui generis legal system. The WTO and its legal order in the international legal order have proven as a catalyst for international mutual respect towards international coherence and even for increased global governance, especially in the international trade law. It is clear that the WTO is both a product and a vehicle for international community evolution.

16 In the context of traditional international legal framework State Sovereignty generally pointed as referral for "the Act of State Doctrine" or "the Sovereign Act Doctrine". This is an international legal doctrine emanating in the $19^{\text {th }}$ century in which it has been affirmed that every sovereign State is bound to respect the independence of every sovereign State, and the courts of one country will not sit in judgment on the acts of the government of another done within its own territory.

17 See also generally Peter van den Bossche, 2005, The Law and Policy of the World Trade Organization Text, Cases and Materials, Cambridge University Press, Cambridge.

18 Robert Howse, "Sovereignty, Lost and Found", in Wen hua Shan, et al., 2008, Redefining Sovereignty in International Economic Law, Oregon, Oxford, pp. 61-62. See also Julian Ku and John Yoo, “Globalization and Sovereignty”, Berkeley Journal Internationall Law, Vol. 31, Issue 1, 2013, p. 210. 
Indeed, the WTO is an international organization that brings together two concepts of international law. It has two unique specificities, in which it is a permanent negotiating forum between sovereign states and is therefore a cooperation organization akin to international conferences established under traditional international law. Apart from that, the WTO also established and implemented a sophisticated dispute settlement mechanism which makes it an integration organization, rooted in contemporary international law. In fact, the WTO's sophisticated dispute settlement mechanism makes it a distinctive organization. ${ }^{10}$

The policy and legal frameworks developed and implemented through the WTO signify that there is now a world trade constitution adopted and enforced globally. ${ }^{20}$ International community has moved from "political constitutionalism" adopted following the Second World War by the establishment of the United Nations, to "economic constitutionalism" by the establishment of the World Trade Organization in 1994. In the context of international economic and trade law there would be "One World, One International System/ Standard "implemented globally. Once the standard implemented, it become very difficult to be withdrawn.

It is clear that at the end of $20^{\text {th }}$ century and in the beginning of 21 th century, there was a transformation on the concept and nuance of the state sovereignty and its implementation in the international community. The change of the society, institutional framework, technological advance as well as the intensity of economic activity among States have led to the revival of the meaning of state sovereignty under the current international system. In historical terms, the practice of States in defining sovereignty within the framework of international relations has long been debated and the debate still continue until now. ${ }^{21}$

In the context of modern international law, the globalization has transformed the function of international law; where the international law has become vehicle for States to cooperate each other regarding new areas of international relations such as: economic and trade, environmental, security and human rights. This situation also necessitates States to rethink the previous notion of the inviolable State sovereignty. Moreover, nowadays States also have choices and outlook to consider response toward globalization process and globalism. States weighed the costs and benefits of the loss of this valuable sovereignty.

It is plausible to underline the notion that in the contemporary international system, globalization has created paradox situation, especially for the third world countries which has been called as "globalization tri-lemma". In this sense, countries cannot have: national sovereignty, hyper-globalization/economic liberalization, and democracy at the same time. They can only ever choose two out of the three, it is not possible to have all three. Thus, it is possible for countries to have two of three things: deep economic integration, democratic politics and autonomous nation-states.

The globalization has also gave the new meaning of the classic issues such as: sovereignty, the role of international organization and or individuals and even the issues concerning border. The on going process of balancing between sovereignty on the one hand ; and humanitarianism, state economic interests, individual freedoom, empowerment of non-state entities on the other hand, should be realized as an indication of the transformation of international law from a system which previously considered as State-centered system to individualcentered system and even more humanized system. This transformation is a continuance of

Pascal Lamy, “The Place of WTO and its Law in the International Legal Order”, The European Journal of International Law (EJIL), Vol. 17, No. 5, 2006, pp. 969-984.

20 See for example Jeffrey L Dunoff, "Why Constitutionalism Now : Text, Context and Historical Contingency of Idea”, Journal of International Law \& International Relations (JILIR), Vol. 1, No. 1-2, pp. 191- 212.

21 Kal Raustiala, "Rethinking the Sovereignty Debate in International Economic Law", Journal of International Economic Law, December, 2003, p. 842. 
the codification and institutionalization of human rights norms and values that had been started since post-World War II by the endorsement of Universal Declaration of Human Rights.

\section{Response to Supranationalism}

Recently we have witnessed that the authority and powers of international organizations, have all evolved in light of the forces of globalization. The powers of international organization is even stronger today. Learning from the international history it seems that different countries have different approach to formulate their response to the challenges presented by globalization. One of the thought-provoking issue deserves to be discussed here is the response of States to the idea of supranationalism. In such a context, it is very logical should we observe the situation which is going on in Europe. More specifically we have to consider the existence of the European Union.

The European Union ( EU ) has survived more than half of a century. Even in the last two decades its existence and development especially in the context of regional integration, has inspired countries and organisations in other regions. The supranationalism paradigm adopted by this regional organisation has provoked and considered as referral by countries and organisations in other regions. Many countries have coceived that European Union is the most developed regional organisation in the world. EU has been consiedered as the role model for a regional integration and liberalization. However, the fact about the vote of England to separate from EU in the 23 June 2016 referendum, after joined more than four decade has been pompting hesitation concerning supranationalism concept. The idea of supranationalism to be hotly debated in the near future. There are many arguments that can be made as to why the United Kingdom should remain within the EU. Conversely, there are also many arguments that can be made as to why the UK should depart from the EU.

More than fivety years ago, European leaders have proposed and designed an international organization with supranational character. The political and legal concept confirmed by the Paris Treaty of 18 April 1951, initially purported as an effort of re-organize and reconstruct Europe democratically after the second World War. The concept of supranationalism grasps a broad and flexible connotation, it could encompass international character, trans-national, even global. The notion proposed by the French Foreign Minister Robert Schumman, initially supported by some Western Europe contries (French, Germany, Italy, the Netherlands, Belgium and Luxemburg), however, later on it has encompassed almost the Europe Continent, as other Western Europe Countries, Britain and eastern Europe have also joined.

There are reasons why supranationalism adopted as an instrument for policy and transnational politic, especially by the European States. First, the power of an international organization is limited and there is assumption that such a power would not has implication to the national authority. Second, generally speaking international organization established by a treaty, thus its power and activities explicitly confirmed by the member and or founder States. In this context, international organization powers and activities should be based on the consent of the members.

In terms of membership, sovereignty is the basis for and expressed in the consent of a State to be a member of and bound by the international organization. The powers of international organization gained from the consent of the member states. The consent given by states is not permanent and could be withdrew any time.

Why EU is so attaractive and inspiring for other regions? In the last five decades, international organizations actively contribute in the making process of international law . European integration with supranational paradigm, has offered incentive for state governance. Supranationalism of EU has offered reasonable governance concepts, such as : rule of law, economic development supported by; integrated and liberalized trade ( single market); monetary system; democratization and human 
rights standards; citizen mobility; cross-border education and human resources qualification; and collective security.

Recently, the supra-nationalism is at stake. There are, at least two reasons why the idea of supranationalism being contested from the bottom side. First, there has been a transformation of the character of international institution from Multilateral Institution to Global Imperium. Secondly, there is a Lack of Legitimacy in the decisian and policy making process and its implication to the constituents, peoples in the member States.

\section{a. Transformation from Multilateral Institution to Global Imperium}

At this time, the state of affairs contemporary global legal and political context, prompted by the strengthening role and power of international organization vis a vis states. The role and power of international organizations are firming while the role and power of State at global level is weakening in the framework of decision and policy making process relevant to the people interests. International organization likewise $\mathrm{EU}$, has became a new imperium. Organization that initially based on multilateral pooled sovereignty transformed to an institution having power of derogating State sovereignty.

Global imperium is a term to illustrate the transformation of international organization turning out as a political and legal entity which is superior than the member Mtates. There is asymetric relationship between international organization and its members. International organization has become dominant and superior in front of the national authorities of the founder states. International organization hegemony has set a side the prerogative of a state to decide issues relevant to the peoples. The dicision making power has been relocated to the hand of international organization , including its implementation and enforcement. The decision of international organization practically has superior normative implication in the territory of the member states.

Consequenly, there is discourse concerning character and the significance of sovereignty and its application in the present international system. The social fransformation, institutional framework and the avancement of technology as well as international economic transaction have driven towards the reinterpretation of sovereignty in the contemporary context of international system. Historically there has been a long debate concerning state practices in the interpretation of sovereignty, and nowadays the debate is even more intriguing in the light of the growing role of international organizations in the international arena.

\section{b. Lack of Legitimacy}

In fact, the character of international organization as global imperium has a significant implication in the decision making process on matter relevant to both in the inter-state relations and even in the domestic policy, especially there is lack of deliberative democracy. Peoples affected by the policy and decision of the international organization are questioning about the accountability and fairness in the decision making process. Citizens in the member state of have considered that decisions of supranational organization are inconsistent or even contradictory with their interests.

Nevertheless, the strengthening role and power of supranational organization which have direct impact to the government, corporations and individuals have aggravated skepticism concerning its legitimacy. The skepticism over its legitimacy, even stronger as the decision making process in such a supranational organization has been dominated by the elite groups and lack of participatory process. Peoples in the member states as the constituents are being left behind in the structural contestation setting in the 
supranational organization.

International organizations are said to lack democratic authority in this respect since their law-making processes generally take place in the seat of organs that are not chosen by the people they are supposed to represent. In this regard, it is commonly alleged that individuals, NGOs and other nonState actors cannot sufficiently influence the decision-making processes of international organizations, which are then thought to lack democratic legitimacy for this reason as well. The decisions and actions of international organizations violate the individual rights of citizens, which is further ground for arguments criticizing these organizations for not upholding democratic principles.

International organization are also criticized due to its role in facilitating and promoting global capitalism and neo-liberalism which have eroding state sovereignty and prerogative of nations in deciding decisive issues. Above and beyond that, integration of States into supranational organization has brought about dis-incentive to its members such as: disparity and gap of economic development and marginalization of local citizen; mass influx of irregular migrants; security problems (terrorism); human trafficking; and trans-national crimes.

It is noteworthy that Brexit referendum signaling a strong indication that the agenda and vision of supranational organization are inconsistent with or even in conflict with the interests and agenda of citizens in the member States. In such a situation stakeholders in the member States might be move forward questioning the legitimacy of such a supranational organization. Should its legitimacy has been questioned, eventually the credibility of supranational organization likewise EU would be in jeopardy. The cost and benefit of supranationalism paradigm would be hotly debated.

In the Brexit referendum of 23 June 2016, England and Wales voted to leave the EU, while Scotland and Northern Ireland voted to remain ${ }^{22}$. Following that, there has been a debate about how the relationship between EU and the United Kingdom would be manage in a new situation and framework. It would be interesting to scrutinize the political and institutional steps taken, or to be taken, both by the UK and by the EU in the context of the post Brexit referendum vote, and into how matters may evolve in the coming months and years from a legal and institutional perspective ${ }^{23}$.

It is clear that there has been criticism about the democracy deficit in international organizations. However, it is not easy to discuss the legitimacy of international organizations and their decisions from the perspective of democracy. Attempts to improve the legitimacy of international organizations from the perspective of democracy include discussions on the rule of law, transparency in the decision-making process, the disclosure of and access to information, and the budget efficiency and prevention of corruption in the international civil service. These are often included in the concept of accountability.

\section{Conclusion}

It is interesting to observe the response of States and international organizations to the globalism and globalization tendencies in the

22 On 23 June 2016, the United Kingdom (UK) voted to leave the European Union (EU) after 43 years of membership. In fact, 52 per cent of the UK citizens that participated in the Brexit referendum voted to leave the EU. Still, Scotland and Northern Ireland, two out of the four UK constituent nations, voted to remain.

23 Miguel Tell Cremades and Petr Novak, "Brexit and the European Union: General Institutional and Legal Considerations", $h t t p: / / w w$. europarl.europa.eu/supporting-analyses, accessed on $13^{\text {th }}$ April 2017. 
future. States and international organizations as the main actor in the international system have to deal with dillematic list of options; whether rhey would like to exploit supranationalism or multilateralism approach.

The costs and benefits of globalization continue to be hotly debated, in the process of seeking the balance between the three competing edges of liberalization, national sovereignty and democratic legitimacy from the constituents. International community needs international institutions, however, such institutions should not turn out into global government that improperly constraints domestic political sovereignty.

Globalisme and international cooperation are important and being considered as a token of civilization in the contemporary international society. The role of international organizations in the contemporary international system remain significant, however, constituents in the member States would judge whether they could maintain their relevance to the constituents interests and keep mutual relatianship with the member States. Otherwise, member states would say goodbye and revoke their participation.

Learning from the process going on in the European countries which have pooled their sovereignty in the hand of a supranational body, it seems that international regional organizations other than Eropean Union would like to consider and make a critical reflection concerning their roadmap on regional integration. States joined such an international supranational organization would likely emphasize that the agenda and vision of a supranational organization must be in line with with the interests and agenda of citizens in the member States. Otherwise, there would be more and more States member departing from such an organization.

Taking into consideration the transformation dealing with the concept and nuance of the state sovereignty and its implementation in the international community and the global trend of liberalization and universalization on the one side; and national interests on the other side, it seems that multilateral institution would likely the most feasible and rational choice for nations, especially for the nations outside Europe continent.

Along with the transformation dealing with the concept and nuance of the state sovereignty and its implementation, there is the need to consider and recommend statist reform in the light of inescapable globalization and globalism. Statist reform is needed especially for the Third World countries in response to supranationalism and the hegemony of international institutions. Statist reform would encompass but not limited to classical issues such as good governance, structural adjustment of national institutions and competition policy. In this regards the Third World States should develop strategies at international level to intercept the negotiations and decision making process in the international institutions. Furthermore, the national authority of the third word States have also creatively develop strategy in advocating human rights of the marginalized peoples in these States.

\section{REFERENCES}

\section{A. Books}

Bossche, Peter van den, 2005, The Law and Policy of the World Trade Organization Text, Cases and Materials, Cambridge University Press, Cambridge.

Brownlie, Ian, 1990, Principles of Public International Law Fourth Edition, Clarendon Press, Oxford.
Dixon, Martin and Corquodale, Robert Mc., 2000, Cases and Materials on Internasional Law:Third Edition, Blackstone Press Limited London.

Hingorani, R.C., 1982, Modern International Law Second Edition, Oxford \& IBH Publishing Co., New Delhi.

International Commission on Intervention and 
State Sovereignty (ICISS), 2001, The Responsibility to Protect: Report of the International Commission on Intervention and State Sovereignty, International Development Research Centre, Ottawa.

Labonte, Melissa, 2013, Human Rights and Humanitarian Norms, Strategic Framing, and Intervention Lessons for the responsibility to Protect, Routledge, New York.

Marcos, Miguel Gonzalez, 2003, The Search for Common Democratic Standards Through Internasional Law, Heinrich Boll Foundation, Washington.

Shan, Wen Hua, et al., 2008, Redefining Sovereignty in International Economic Law, Oregon, Oxford.

Wouters, Jan and Man, Philip De, 2009, International Organization as Law-Makers, Centre for Global Governance Studies Katholieke Universiteit Leuven, Leuven.

\section{B. Internet}

Cremades, Miguel Tell and Novak, Petr, "Brexit and the European Union: General Institutional and Legal Considerations", http://www. europarl.europa.eu/supporting-analyses, accessed on $13^{\text {th }}$ April 2017.

\section{Journal Articles}

Bartelson, Jens, "The Concept of Sovereignty Revisited," European Journal of International Law, April, 2006.

Bassiouni, M. Cherif, "International Crime : Jus Cogens and Obligatio Erga Omnes", Law and Contemporary Problem, Vol. 59, No. 4, 1996.

Dunoff, Jeffrey L., "Why Constitutionalism Now: Text, Context and Historical Contingency of Idea", Journal of International Law \&
International Relations (JILIR), Vol. 1, No. $1-2$.

$\mathrm{Ku}$, Julian and Yoo, John, "Globalization and Sovereignty”, Berkeley Journal Internationall Law, Vol. 31, Issue 1, 2013.

Lamy, Pascal, "The Place of WTO and its Law in the International Legal Order", The European Journal of International Law (EJIL), Vol. 17, No. 5, 2006.

Reisman, W. Michael, " Legal responses to Genocide and Other Massive Violations of Human Rights", Law and Contemporary Problem, Vol. 59, No. 4, 1996.

Rodrik, Dani, "How to save Globalization from its Cheerleaders", The Journal of International Trade and Diplomacy, Vol.1, No. 2, 2007.

Sato, Tetsuo, "Legitimacy of International Organizations and Their DecisionsChallenges that International Organizations Face in the 21st Century", Hitotsubashi Journal of Law and Politics, Vol. 37, No. 2, 2009 ..

Sathirathai, Surakiart, "Renewing Our Global Values: A Multilateralism for Peace, Prosperity, and Freedom", Harvard Human Rights Journal, Vol. 19, 2006.

\section{Research Report}

Olin, John M., 2008, Public Law and Legal Theory, Working Papers No. 224, University of Chicago Law School, Chicago.

Posner, Eric A., 2008, Erga Omnes: Norms, Institutionalization, and Constitutionalism in International Law, Working Papers, University of Chicago Law School, Chicago.

\section{E. Regulations}

Barcelona Traction case [(Belgium vs Spain) (Second Phase) ICJ Rep 1970. 